\title{
Isoenzyme variation in the common shrew (Sorex araneus) in Britain, in relation to karyotype
}

\author{
J. B. Searle*
}

\begin{abstract}
Department of Genetics, University of Aberdeen,
\end{abstract} Tillydrone Avenue, Aberdeen AB9 2TN.

Samples of common shrews with an Aberdeen race, Oxford race and Hermitage race karyotype and from the OxfordHermitage hybrid zone were screened for genotype at six polymorphic enzyme loci. The common allele at all loci was the same in all samples suggesting that the degree of genic divergence between the karyotypic races is not great. However, shrews of the Aberdeen race appear to be somewhat distinct. There were differences in allele frequencies, range of alleles and heterozygosities at the $\mathrm{Mpi}$-1, Pgm-2 and $\mathrm{Pgm}$-3 loci between the Aberdeen race samples and samples of other karyotypic categories. The allele frequency variation across the Oxford-Hermitage hybrid zone is not substantially linked with karyotype frequency change, but there is notable allele frequency variation between close sites of similar habitat, particularly at the $P g m-2$ and $P g m-3$ loci. This suggests that gene flow between close sites may be reduced sufficiently in some instances to allow allele frequency change by genetic drift. This may have implications for the mode of origin of karyotypic races of common shrew.

\section{INTRODUCTION}

The common shrew (Sorex araneus) is one of the most karyotypically variable mammals known. Over its wide distribution in the northern Palaearctic there are at least 12 karyotypic races of which three have been found in Britain: the "Aberdeen race" in northeastern Scotland, the "Oxford race" in southern Scotland and central and northern England and the "Hermitage race" in southeastern England (Searle, 1984a). Phylogenetic analysis based on karyotype indicates that the three British races of common shrew are more closely related to each other and to races found elsewhere in central and northwestern Europe than to other more geographically distant karyotypic races (Searle, 1984a).

One may expect karyotypic differentiation to be accompanied by some degree of genic divergence, whether it is believed that karyotypic difference provides an important barrier to gene flow between races (e.g., White, 1978) or that a difference in chromosome complement is likely to be little more than a marker for more important genic differences (e.g., Barton, 1980). In this paper the extent to which the British karyotypic races of common shrew differ genically from one another

* Present address: School of Biological Sciences, University of East Anglia, Norwich, NR4 7TJ. is examined, using enzymes as easily scored markers. In the first analysis, the extent of genic divergence between geographically separated samples of different karyotypic race is considered. In the second analysis, a comparison is made between the pattern of karyotypic variation and enzyme allele variation around an area of contact and hybridisation between the Oxford and Hermitage races.

\section{MATERIALS AND METHODS}

Common shrews were removed from small, marginal areas of grassland over the years 1980 to 1983. Each sample was collected from a continuous trapping area of $2.6 \mathrm{Ha}$ or less within a 10 day period. The collection site locations are given in fig. 1 (see Searle, 1984a for grid references). Samples from a particular site consisted of either immatures only or adults only. Thus, on the basis of life history studies of the common shrew (Crowcroft, 1957), all animals within a sample can be considered to be approximately the same age. Study was concentrated on immature animals because it was easier to catch the large numbers of individuals desirable for allele frequency studies. In general, 30 individuals were analysed for each site. However, details of the informative 


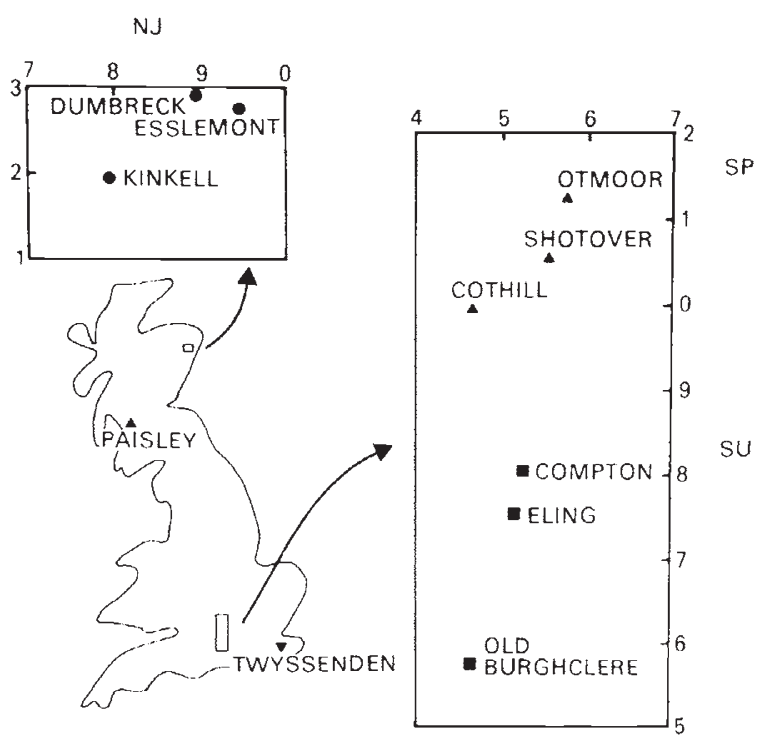

Figure 1 Sample sites in Britain with the Aberdeen and Oxford areas shown in greater detail (10-kilometre divisions of the National Grid are indicated). (O) Aberdeen race sample; (A) Oxford race sample; ( $\boldsymbol{\nabla})$ Hermitage race sample; ( $\mathbf{\square})$ Oxford-Hermitage hybrid zone sample.

smaller samples from Paisley and Twyssenden are also included.

All animals described in this paper were karyotyped (see Searle, 1984a) and samples were designated according to whether they consisted of individuals with Aberdeen, Oxford or Hermitage race karyotypes. The Oxford-Hermitage hybrid zone samples each included some individuals with a hybrid karyotype.

In a preliminary study, methods for detection of a variety of enzyme systems were tested on common shrew tissue samples from different parts of the country. Six enzyme systems were found to be variable and could be easily and consistently scored. They were as follows: three phosphoglucomutase (E.C. 2.7.5.1) systems (PGM-1, -2,-3), one lactate dehydrogenase (E.C. 1.1.1.27) system (LDH-2), one mannose phosphate isomerase (E.C. 5.3.1.8) system (MPI-1) and one esterase (E.C. 3.1.1) system (ES-1). The isoenzymes and their variation are described in terms of the standard nomenclature for the mouse (Lyon, 1981).

Kidney tissue was used for enzyme preparation. Whole kidneys were washed in physiological saline $(0.145 \mathrm{M} \mathrm{NaCl})$ and frozen down within $30 \mathrm{~min}$ of death. Routinely, samples were stored frozen $(-20$ or $-70^{\circ} \mathrm{C}$ ) for up to 6 months before analysis. The tissue was hand-homogenised on ice with $0 \cdot 1$ per cent $(\mathrm{v} / \mathrm{v})$ Triton $\mathrm{X}-100$ in $50 \mathrm{mM}$ Tris- $\mathrm{HCl} \mathrm{pH} 8.0$ in the ratio $1 \mathrm{~g}$ tissue: $3 \mathrm{ml}$ buffer and then centrifuged at $15,000 \mathrm{~g}$ for 60 minutes at $4^{\circ} \mathrm{C}$. Usually the supernatant could be applied to the electrophoretic medium without pretreatment, but for PGM isoenzymes it was incubated for at least 1 hour at $4^{\circ} \mathrm{C}$ with mercaptoethanol to reverse sulphydryl modification (Harris and Hopkinson, 1976).

The tissue samples were run on $94 \times 76 \mathrm{~mm}$ Titan III cellulose acetate plates (Helena Laboratories Co., Beaumont, Texas, U.S.A.) at $200 \mathrm{~V}$ and room temperature using a continuous buffer system. For PGM-2 this buffer was $40 \mathrm{mM}$ Tris $-10 \mathrm{mM}$ citrate $p \mathrm{H} 7.6$ with a run time of 20 minutes. For other systems it was $25 \mathrm{mM}$ Tris$0.19 \mathrm{mM}$ glycine $p \mathrm{H} 8.5$ with a run time of 30 minutes. Stain was applied as an agar overlay. Approximate final concentrations of histochemicals on the gels were as follows: esterase: $36 \mathrm{mM}$ Tris- $\mathrm{HCl} p \mathrm{H} 7 \cdot 1,3 \cdot 6 \mathrm{mM} \alpha$-napthyl propionate, $1.8 \mathrm{mM}$ Fast Blue RR salt; lactate dehydrogenase: $80 \mathrm{mM}$ Tris- $\mathrm{HCl} p \mathrm{H} 8.0,0.30 \mathrm{mM}$ NAD, $67 \mathrm{mM}$ lactate $p \mathrm{H} 8.0,0.23 \mathrm{mM}$ PMS, $0.67 \mathrm{mM}$ MTT; mannose phosphate isomerase: $91 \mathrm{mM}$ Tris- $\mathrm{HCl} p \mathrm{H} 8.0, \quad 0.30 \mathrm{mM}$ NADP, $0.62 \mathrm{mM}$ D-mannose-6-phosphate, $1 \cdot 1$ i.u. G6PD ml ${ }^{-1}$, 1.5 i.u. PGI $\mathrm{ml}^{1}, 0.26 \mathrm{mM}$ PMS, $0.76 \mathrm{mM}$ MTT; phosphoglucomutase: $81 \mathrm{mM}$ Tris- $\mathrm{HCl} p \mathrm{H} \mathrm{8} \cdot 0,0 \cdot 26 \mathrm{mM}$ NADP, $34 \mathrm{mM} \mathrm{mag}$ nesium acetate, $17 \mathrm{mM} \alpha$-D-glucose-1-phosphate, 1-1 i.u. G6PD ml "', $0 \cdot 14$ mM PMS, $0 \cdot 41 \mathrm{mM}$ MTT.

After staining was complete, the agar overlay was washed off and the gels dried. The position of each putative allelic product relative to a standard (an isoenzyme of the CBA inbred mouse strain) was scored by measurement.

\section{RESULTS}

\section{(i) Isoenzyme phenotypes and their inheritance}

The range of phenotypes for all six enzyme systems scored could be most simply explained by codominant expression of a number of alleles inherited in a Mendelian fashion. Putative homozygotes of each allele of each enzyme had single band phenotypes and heterozygotes multiple band phenotypes. From the band pattern in heterozygotes, it could be concluded that MPI-1 and PGM-1, -2 and -3 are monomeric and ES-1 trimeric in structure. $\mathrm{LDH}$, as in other mammals, appears to have a tetrameric structure coded for by two loci of which the putative locus $L d h-2$ was found to be variable in the common shrew. The 
range of phenotypes observed are illustrated in Searle (1983 and in press). (Note that in addition to those allelic products and phenotypes described in Searle (1983) a new product: PGM-1D which migrates $-7 \mathrm{~mm}$ from the standard and three new phenotypes: PGM-1AD, MPI-1CC and PGM$3 \mathrm{AD}$ were recorded.)

Using the breeding system developed by Searle $(1984 b)$, a number of crosses were set up to examine the inheritance of alleles at putative enzyme loci. These crosses confirmed the Mendelian basis of inheritance of alleles at the most variable of the putative loci: $M p i-1, P g m-2$ and $P g m-3$ (see Searle, 1983 for details). The tissue distribution, substrate characteristics and pattern of migration of MPI-1, PGM-1, ES-1 and LDH-2 isoenzymes indicated their homology with MPI-1, PGM-2, ES-6 and LDH-2 isoenzymes in the mouse, respectively, and the variation of these isoenzymes in the shrew can therefore be considered, by analogy with the mouse, to be under simple genetic control. Thus it may reasonably be assumed that all the putative allelic variation under consideration is under the control of true genetic loci and follows a simple Mendelian pattern.

\section{(ii) Allele frequency variation between the races}

None of the alleles detected was diagnostic for a karyotypic race. In fact, the common allele of each locus was the same in all samples examined (table 1). However, for certain loci there was variation in both allele frequency and mean heterozygosity (i.e., proportion of individuals in sample that were heterozygotes) between samples (tables 1,2), particularly between the large samples of immatures collected in the Aberdeen area and the area of the Oxford-Hermitage hybrid zone (which will be known as the Oxford area; see fig. 1). The most striking differences between the Oxford and Aberdeen areas were those detected at the $M p i-1$ locus. While there was a high level of polymorphism in the Oxford area with heterozygosities of 0.40 or more, a maximum frequency of the commonest allele of 0.68 and up to six alleles present at a site, the Aberdeen sites were virtually monomorphic for the $M p i-1^{\text {a }}$ allele. At the Pgm-3 locus, there was not such a great discrepancy, but again the commonest allele was less frequent, heterozygotes were more common and more alleles were observed at sites in the Oxford area than in the Aberdeen area, while there was a reverse tendency for $P g m$-2. There were no such clear trends with the Es-1, Ldh-2 or Pgm-1 loci, which showed low level polymorphism.

The allele frequencies, range of alleles and heterozygosities of the $\mathrm{Mpi}-1, \mathrm{Pgm}-2$ and $\mathrm{Pgm}-3$ loci for the Oxford race sample of Paisley more closely resembled samples from the Oxford area than Aberdeen area samples (tables 1,2), although Paisley is geographically closer to Aberdeen than Oxford. This suggests that the differences between the Oxford and Aberdeen areas are the result of racial differences (Aberdeen area: Aberdeen race; Oxford area: Oxford, Hermitage races) rather than a consequence of differing geographical location. However, the Paisley sample was small, so this interpretation must be considered tentative.

The characteristics of allelic variation (particularly at the Pgm-3 and Mpi-1 loci) of the Hermitage race sample at Twyssenden are also more similar to those of samples from the Oxford area than to those of samples from the Aberdeen area (tables 1,2). To provide an indication of the allelic differences between the Hermitage and Oxford races, the Twyssenden sample and hybrid zone sample of Old Burghclere (of which 87 per cent of individuals had a Hermitage race karyotype) can be compared with the Oxford race samples of Paisley, Otmoor, Shotover and Cothill. There are no convincing differences in terms of allele frequencies and heterozygosity for each locus scored between the Oxford and predominantly Hermitage race samples. However, the range of alleles is greater (i.e., there are more rare alleles) at each site in the Oxford race samples for the $M p i-1$ locus and in the predominantly Hermitage race samples for the $P g m-1$ locus.

\section{(iii) Allele frequency variation within the Oxford area}

Within the Oxford area there is dramatic karyotypic variation, with the Oxford race exclusively to the north and the Hermitage race predominating to the south (Searle, in preparation). There is no similar striking variation at the enzyme loci, although the frequency of the $M p i-1^{\mathrm{a}}$ allele is slightly but consistently higher in the hybrid zone samples than in the Oxford race samples (table 1). Also, the range of alleles and heterozygosities at this locus are always less in the hybrid zone samples (tables 1,2).

The most dramatic variation in allele frequencies in the Oxford area is apparently unrelated to karyotype, with large frequency differences between karyotypically similar samples from close sites, e.g. at Shotover the frequency of $P g m-2^{a}$ is 
Table 1 The allele frequencies

\begin{tabular}{|c|c|c|c|c|c|c|c|c|c|c|}
\hline \multirow[b]{3}{*}{ Site* } & \multirow[b]{3}{*}{ Racet } & \multirow[b]{3}{*}{$\mathrm{N}$} & \multirow[b]{3}{*}{ Life stage } & \multirow{3}{*}{$\begin{array}{l}\text { Date of } \\
\text { capture }\end{array}$} & \multicolumn{6}{|c|}{ Frequency } \\
\hline & & & & & \multicolumn{4}{|l|}{$E s-1$} & \multicolumn{2}{|c|}{$L d h-2$} \\
\hline & & & & & a & $b$ & $\mathrm{c}$ & $\mathrm{d}$ & $\mathrm{a}$ & $\mathrm{b}$ \\
\hline Dumbreck & $\mathrm{A}$ & 30 & $\mathrm{imm}$ & $1-2 / 81$ & 0.95 & 0.05 & & & $1 \cdot 00$ & \\
\hline Esslemont & A & 30 & $\mathrm{imm}$ & $11-12 / 80$ & 0.95 & 0.05 & & & $1 \cdot 00$ & \\
\hline Kinkell & A & 30 & $\mathrm{imm}$ & $12 / 80$ & 0.90 & $0 \cdot 10$ & & & $1 \cdot 00$ & \\
\hline Paisley & $\mathrm{O}$ & 9 & ad & $4 / 81$ & 0.83 & $0 \cdot 11$ & & $0 \cdot 06$ & $1 \cdot 00$ & \\
\hline Otmoor & $\mathrm{O}$ & 30 & $\mathrm{imm}$ & $9 / 80$ & 0.98 & 0.02 & & & 1.00 & \\
\hline Shotover & $\mathrm{O}$ & 30 & $\mathrm{imm}$ & $9 / 80$ & 0.98 & 0.02 & & & 0.93 & 0.07 \\
\hline Cothill & $\mathrm{O}$ & 30 & $\mathrm{imm}$ & $9 / 81$ & 0.83 & 0.08 & 0.08 & & 0.97 & 0.03 \\
\hline Compton & $\mathrm{hz}$ & 30 & $\mathrm{imm}$ & $8 / 81$ & 0.95 & 0.05 & & & $1 \cdot 00$ & \\
\hline Eling & $\mathrm{hz}$ & 30 & $\mathrm{imm}$ & $9 / 81$ & $1 \cdot 00$ & & & & $1 \cdot 00$ & \\
\hline Old Burghclere & $\mathrm{hz}(\mathrm{H})$ & 30 & $\mathrm{imm}$ & $9 / 83$ & 0.98 & $0 \cdot(02$ & & & 0.95 & 0.05 \\
\hline Twyssenden & $\mathrm{H}$ & 7 & $\mathrm{imm}$ & $10 / 83$ & $1 \cdot 00$ & & & & $1 \cdot 00$ & \\
\hline
\end{tabular}

* Sequence according to latitude with most northerly first.

$\dagger \mathrm{A}=$ Aberdeen, $\mathrm{O}=$ Oxford, $\mathrm{H}=$ Hermitage, $\mathrm{hz}=$ Oxford-Hermitage hybrid zone sample, hz $(\mathrm{H})=$ Oxford-Hermitage hybrid zone sample, predominantly Hermitage race individual's.

Table 2 Mean heterozygosities for each locus and total number of alleles at each site

\begin{tabular}{|c|c|c|c|c|c|c|c|c|c|}
\hline \multirow[b]{2}{*}{ Site* } & \multirow[b]{2}{*}{ Race* } & \multirow[b]{2}{*}{$E s-1$} & \multirow[b]{2}{*}{$L d h-2$} & \multicolumn{5}{|c|}{ Mean heterozygosity } & \multirow{2}{*}{$\begin{array}{l}\text { Total no. } \\
\text { of alleles }\end{array}$} \\
\hline & & & & Mpi-1 & $P g m-1$ & $P g m-2$ & $P g m-3$ & per locust & \\
\hline Dumbreck & $\mathrm{A}$ & 0.10 & 0 & 0.07 & 0 & 0.53 & 0.17 & $0 \cdot 14$ & 10 \\
\hline Esslemont & A & $0 \cdot 10$ & 0 & $0 \cdot 10$ & $0 \cdot 10$ & $0 \cdot 40$ & 0.23 & $0 \cdot 16$ & 13 \\
\hline Kinkell & A & $0 \cdot 20$ & 0 & 0.07 & $0 \cdot 10$ & 0.53 & 0.17 & $0 \cdot 18$ & 13 \\
\hline Paisley & $\mathrm{O}$ & $0 \cdot 22$ & 0 & 0.44 & 0 & 0.44 & 0.44 & $0 \cdot 26$ & 14 \\
\hline Otmoor & $\mathrm{O}$ & 0.03 & 0 & 0.53 & 0 & $0 \cdot 30$ & 0.57 & $0 \cdot 24$ & 15 \\
\hline Shotover & $\mathrm{O}$ & 0.03 & $0 \cdot 13$ & 0.57 & 0 & 0.67 & 0.63 & 0.34 & 15 \\
\hline Cothill & $\mathrm{O}$ & $0 \cdot 30$ & 0.07 & 0.67 & 0 & 0.23 & 0.37 & 0.27 & 16 \\
\hline Compton & $\mathrm{hz}$ & $0 \cdot 10$ & 0 & 0.40 & 0 & 0.13 & $0 \cdot 47$ & $0 \cdot 18$ & 13 \\
\hline Eling & $\mathrm{hz}$ & 0 & 0 & 0.40 & 0 & $0 \cdot 30$ & 0.47 & $0 \cdot 19$ & 10 \\
\hline Old Burghclere & $h z(\mathrm{H})$ & 0.03 & $0 \cdot 10$ & 0.40 & 0.03 & 0.40 & 0.53 & $0 \cdot 25$ & 15 \\
\hline Twyssenden & $\mathrm{H}$ & 0 & 0 & 0.71 & 0.14 & 0.29 & 0.43 & $0 \cdot 26$ & 12 \\
\hline
\end{tabular}

* See Table 1.

+ Note that this is only based on the described sample of polymorphic loci; it is not an estimate of average heterozygosity over the entire genome.

much lower than nearby Otmoor and Cothill and at Cothill the frequency of $\mathrm{Pgm}-3^{\mathrm{a}}$ is considerably higher than at adjacent sites. This heterogeneity is significantly greater than expected for Pgm-2 and Pgm-3 whether all samples from the Oxford area or just Oxford race samples are considered (table 3).

There is no evidence for genic heterogeneity within a sample site. Such heterogeneity may be expressed as an excess of homozygotes over that anticipated from the Hardy-Weinberg equilibrium (the Wahlund effect). Considering all loci at all sites, altogether 25 tests of goodness-of-fit of genotype frequencies to the Hardy-Weinberg expectation satisfied statistical requirement. In no case was there a significant departure from expectation and no overall tendency for heterozygote excess or deficiency.

\section{DISCUSSION}

In common with an associated morphometric study (Searle and Thorpe, in preparation), this study of isoenzyme variation has revealed relatively little genic differentiation between the karyotypic races of common shrew in Britain. However, although there are no diagnostic enzyme alleles which distinguish the races, the differences in allele frequencies at the $P g m-2, P g m-3$ and particularly 


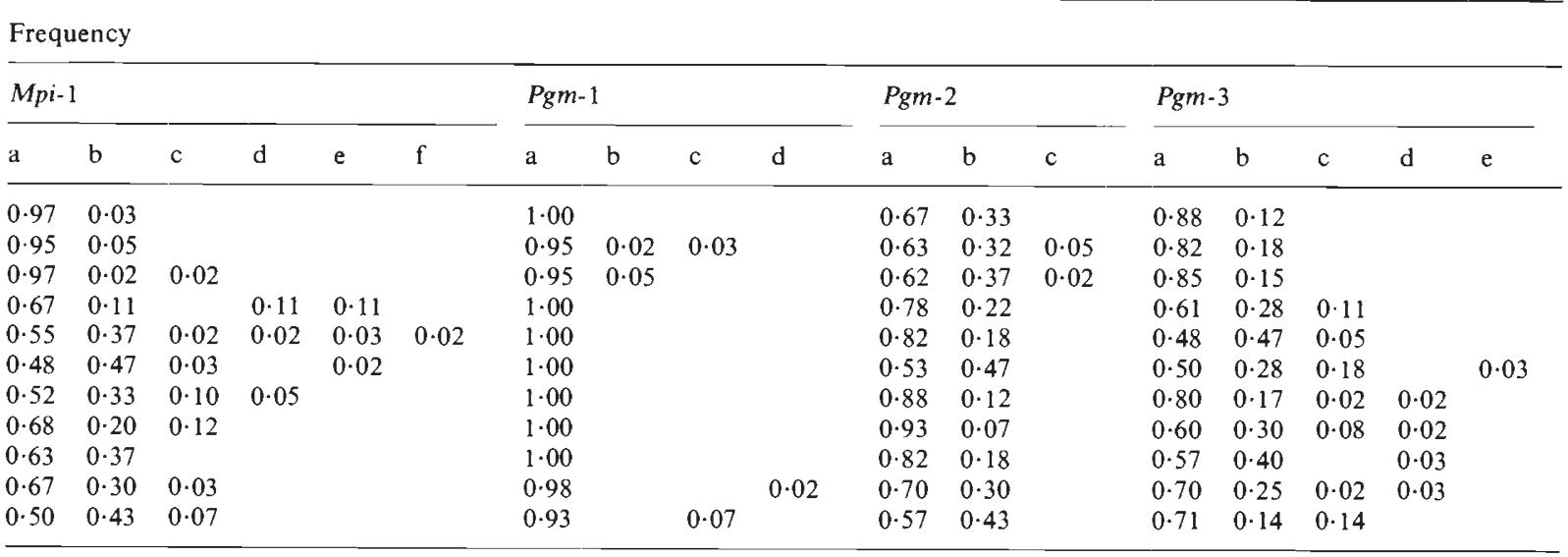

Table 3 Tests for homogeneity of allele frequencies between samples in the Oxford area

\begin{tabular}{|c|c|c|c|}
\hline \multirow{2}{*}{$\begin{array}{l}\text { Isoenzyme } \\
\text { locus }\end{array}$} & \multicolumn{3}{|c|}{ Tests for homogeneity* } \\
\hline & $x^{2}$-value & $\mathrm{df}$ & $p$ \\
\hline \multicolumn{4}{|c|}{ Oxford race samples ${ }^{\dagger}$} \\
\hline$M p i-1$ & $5 \cdot 04$ & 4 & $>0.05$ \\
\hline Pgm-2 & $21 \cdot 78$ & 2 & $<0.001$ \\
\hline Pgm-3 & $29 \cdot 50$ & 4 & $<0.001$ \\
\hline \multicolumn{4}{|c|}{ Hybrid zone samplesł } \\
\hline Mpi-1 & $0 \cdot 35$ & 2 & $>0.05$ \\
\hline$P g m-2$ & 10.91 & 2 & $<0.01$ \\
\hline Pgm-3 & $2 \cdot 46$ & 2 & $>0.05$ \\
\hline \multicolumn{4}{|l|}{ All samples } \\
\hline Mpi-1 & $8 \cdot 63$ & 5 & $>0.05$ \\
\hline$P g m-2$ & $36 \cdot 47$ & 5 & $<0.001$ \\
\hline$P g m-3$ & $20 \cdot 43$ & 5 & $<0.01$ \\
\hline
\end{tabular}

* To satisfy statistical requirements (Siegel, 1956), classes of rare alleles were sometimes combined.

† Otmoor, Shotover, Cothill.

$\ddagger$ Compton, Eling, Old Burghclere.

the Mpi-1 locus between the Aberdeen race samples and the Oxford and Hermitage race samples suggests that the karyotypic races have diverged somewhat. In addition, the slight differences between Oxford race and Oxford-Hermitage hybrid zone samples and between the Oxford race and predominantly Hermitage race samples may reflect differentiation between the Oxford and Hermitage races, but further studies are required to substantiate this.

It is not possible to fully assess the extent to which genic differences between the karyotypic races relates to the structure of the zones of contact between them. The cytogenetic characteristics of the Oxford-Hermitage hybrid zone are such that one would expect extensive gene flow between the Oxford and Hermitage races (Searle, in preparation). This is consistent with the similarity in enzyme allele frequency between these races. Nothing is known about the area of contact between the Oxford and Aberdeen races. However, given that these races exhibit greater genic differentiation than the Oxford and Hermitage races, it is obviously of interest to determine whether the cytogenetic characteristics of this area of contact are such that gene flow is likely to be restricted.

An independent study of isoenzyme variation in the common shrew in Sweden also indicates little genic differentiation, although, as in the present study, there were marked differences in allele frequency at a mannose phosphate isomerase locus (presumably $M p i-1$ ) between karyotypic races (Frykman et al., 1983). Thus there is strong evidence that there has been (and perhaps still is) a degree of interruption to the flow of $M p i-1$ alleles between at least some karyotypic races of common shrew.

A further element of isoenzyme variation, apparently unrelated to karyotype, was that between close sites in the Oxford area, particularly at the Pgm-2 and Pgm-3 loci. This heterogeneity did not show any regularity with regard to site location or date of collection (see table 1) and occurred between sites of similar habitat. Therefore it is considered more likely to have come about by genetic drift permitted by at least a temporary reduction of gene flow between close sites than the result of local selection pressures. Similar heterogeneity in allele frequencies has been demonstrated in other small mammals, e.g., house 
mouse (Selander, 1970), Florida deer mouse (Smith et al., 1973). It is perhaps surprising that there should be such genetic subdivision in the common shrew, as this species is catholic in its habitat requirements (Corbet, 1966) and it is wellknown from ecological studies that adult male common shrews roam widely during the breeding season in search of mates (Shillito, 1963; Buckner, 1969), a factor which should greatly promote gene flow. Clearly, despite these factors, the isoenzyme data suggest that common shrews within a small area may become at least partially isolated from other individuals of the same species for at least a few generations. The possible influence of genetic drift in the population genetics of the common shrew is of some interest as genetic drift has been implicated as one factor that may aid chromosome spread through the range of a species (White, 1978; Hedrick, 1981). This may have some significance in the consideration of the mode of formation of the karyotypic races of the common shrew.

Acknowledgements This work was supported by an SERC: studentship supervised by Professor F. W. Robertson. I thank P. King and Dr J. Peters for technical advice. I am also grateful to Dr J. R. Clarke and the Department of Agricultural Science, University of Oxford for laboratory facilities and to Professor F. W. Robertson and Drs G. M. Hewitt, R. K. Butlin and A. E. Douglas for reading the manuscript.

\section{REFERENCES}

BARTON, N. H. 1980. The fitness of hybrids between two chromosomal races of the grasshopper Podisma pedestris. Heredity, 45, 47-59.
RUCKNI:R, C. H. 1969. Some aspects of the population ecology of the common shrew, Sorex araneus, near Oxford, England. J. Mammal., 50, 326-332.

CORBET, (;. B. 1966. The Terrestrial Mammals of Western Europe, Foulis, London.

(:ROWC:ROHT, P. 1957. The Life of the Shrew, Reinhardt, London. FRYKMAN, 1., SIMONSEN, V. ANI) BFN(TTSSON, B. (). 1983. Genetic differentiation in Sorex. I. Electrophoretic analysis of the karyotypic races of Sorex araneus in Sweden. Hereditas, 99, 279-292.

HARRIS, H. AND HOPKINSON, D. A. 1976. Handbook of Enzyme Electrophoresis in Human Genetics. North-Holland, Amsterdam.

HEDRICK, P. W. 1981. The establishment of chromosomal variants. Evolution, 35, 322-332.

LYON, M. F. 1981. Rules and guidelines for gene nomenclature. In Green, M. C. (ed.) Genetic Variants and Strains of the Laboratory Mouse, Gustav Fisher Verlag, Stuttgart.

SEARLE, J. B. 1983. Robertsonian chromosomal variation in the common shrew Sorex araneus L. Ph.D. Thesis, University of Aberdeen.

SEARLE, J. B. 1984 a Three new karyotypic races of the common shrew Sorex araneus (Mammalia: Insectivora) and a phylogeny. Syst. Zool., 33, 184-194.

SEARLE. J. B. 1984h. Breeding the common shrew (Sorex araneus) in captivity. Lab. Animals, 18, 359-363.

SEARLE, J. B.. A trimeric asterase in the common shrew (Sorex araneus). $J$. Hered. (in press).

SELANDER, R. K. 1970. Behavior and genetic variation in natural populations. Am. Zool., 10, 53-66.

SMITH, M. H., SELANDER, R. K. AND JOHNSON, W. E. 1973. Biochemical polymorphism and systematics in the genus Peromyscus: III. Variation in the Florida deer mouse (Peromyscus floridanus), a Pleistocene relict. J. Mammal., 54, $1-13$.

SHILliTO, J. F. 1963. Observations on the range and movements of a woodland population of the common shrew Sorex araneus L. Proc: zool. Soc. Lond., 140, 533-546.

SIEG;E. s. 1956. Nonparametric Statistics for the Behavioral Sciences, McGraw-Hill Kogakusha, Tokyo.

WHIT cisco. 